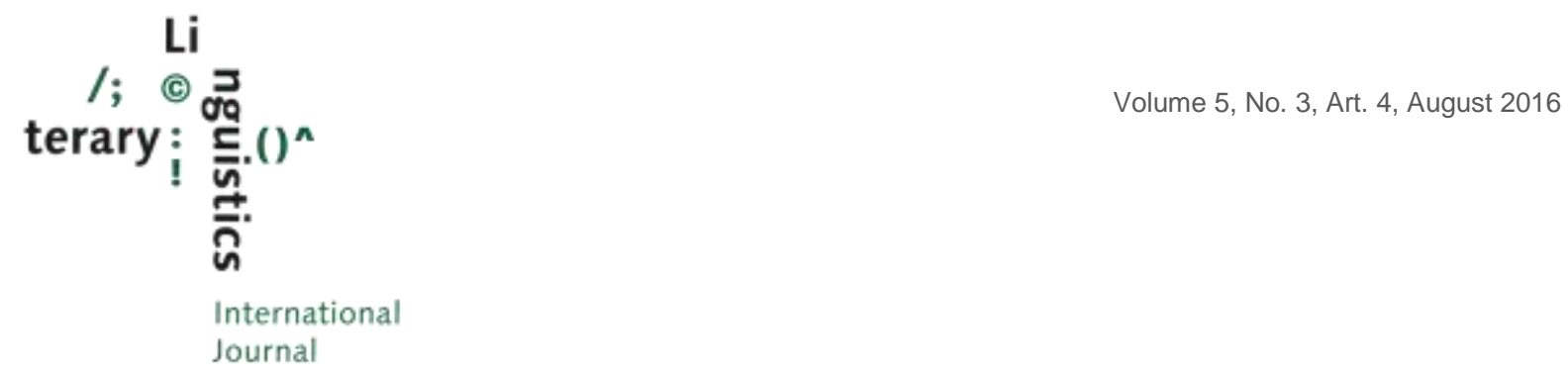

\title{
Changing Norms in Translated Finnish Fiction: A Study of Non-standard Varieties
}

\author{
Keywords: \\ literary \\ translation, \\ norms, \\ strategies, \\ linguistic \\ variation, \\ Finnish
}

\author{
Liisa Tiittula, University of Helsinki, and Pirkko Nuolijärvi, Institute for the \\ Languages of Finland
}

\section{Introduction}

In this article, we examine Finnish translations of varieties of spoken language in fiction from the late $19^{\text {th }}$ century to the beginning of the 2000s. Our aim is to present and discuss the results of a comprehensive study on the changes and developments of translational norms over time in one national literary system consisting of several subsystems, in this case that in Finland.

The overall translation strategy for rendering non-standard speech varies from the use of standard language to the use of a local variety or a mixture of different varieties of the target language. Many studies, however, indicate that the language of translations is marked by less non-standard language than the language of the source texts (cf. Englund Dimitrova 1997). Such studies have typically concentrated on analysing a few works by comparing the source texts and their translations in respect to spoken language variation. In these instances, however, it is rarely considered that norms and conventions regarding the representation of speech also vary in domestic literature across cultures, literary systems and time. In the present article, the hypothesis of standardization is discussed, but translations are examined as part of the whole literary system of the period in question. The focus is not only on the translations but also on their source texts, and trends in non-translated Finnish fiction are also taken into account. The article is based on the findings of Tiittula and Nuolijärvi (2013), a comprehensive study of the ways the illusion of speech 
has been created in original Finnish fiction and works in Finnish translation from the late $19^{\text {th }}$ century to the beginning of the 2000s. The linguistic analysis consisted of qualitative analysis investigating the occurrence, usage and function of phonological/orthographical, morphological, lexical, syntactic and interactional features in the texts across time. The present article is a summary of the findings on translations; the discussion of norms, however, goes beyond it.

In this article, the following questions are posed:

1) How have representations of spoken language in different literary genres been translated into Finnish at various times? Or more specifically:

- How is spoken language translated?

- How are the linguistic variation of a language community and the diversity of spoken language represented in translations?

- What means are used to express speech?

- What are the general translation strategies used?

2) Can we identify the norms underlying the translation of spoken language variation?

Before examining the translations, we will provide an overview of what we call "the Finnish literary polysystem" (cf. Even-Zohar 1990 [1979]) and its development in order to demonstrate the role of translated literature within that system. Thereafter, the data and methods of this study are described. Next, general tendencies, translation universals and strategies regarding the translation of spoken language varieties are discussed. The most important section deals with developments and changes in the translation of literary spoken language: after a general introduction to the norms, an example of changing norms is presented on the basis of retranslations, and translation tendencies in three genres are studied. Finally, we outline general tendencies and discuss the concept of a norm in connection with translation.

\section{A brief history of the development of Finnish literature}

Finnish fiction has a relatively short history. Until the middle of the $19^{\text {th }}$ century, there were but a few original works written in Finnish, most of them religious or legal texts. By the end of the $19^{\text {th }}$ century, the proportion of original Finnish works of fiction had increased to over 40 per cent (Kovala 1992: 192). Even today, around half the works of published literary fiction are translations, and in other genres the proportion is even greater (Finnish Book Publishers Association 2015).

The first period of Finnish literature and the increase of works translated into Finnish occurred at the end of the $19^{\text {th }}$ century, when the language of standard written Finnish was consciously developed; although written Finnish had arrived at its modern standard form, the development of the genre-specific norms of 
language use was still marked by dynamic change (Häkkinen 1994 and 2007). Hence, the role of translations was especially important for both Finnish language and literature: translations were consciously promoted in order to develop original Finnish writing, and translated texts gave models for Finnish literary language and forms of literature. Translators and authors played an important role in influencing the nascent norms of standard written Finnish. At the turn of the $20^{\text {th }}$ century, the role of dialects and dialectal forms as well as the consolidation of spelling and grammar in standard Finnish and literary fiction were intensely discussed (see e.g. Paunonen 1976; Laitinen 2011).

The relationship between translated and domestic literature can be investigated in the light of the polysystem theory introduced by Itamar Even-Zohar (1990 [1979]; see also Hermans 1999). According to Even-Zohar, literature can be seen as a polysystem comprised of a network of systems with a centre and a periphery, the centre being more dominant. The complex of systems is open, dynamic and flexible and in constant change: rather than being fixed, the status of a given system can change between the centre and the periphery, with the borders constantly shifting. When a national language is developing, translated works can be more dominant, and translations serve as models for new domestic texts, as was the case in Finland. Accordingly, at the turn of the $20^{\text {th }}$ century, the position of translations can be regarded as central in Finnish literature. However, as domestic literature developed and became established, it moved to the centre, where, in turn, it became the pioneer of innovations and a source of norms for translated literature, which had moved to the periphery and become more dependent. Nevertheless, works on the periphery can also be innovative and have an effect on the whole literary system and literary language. A good example of the impact of translations on original, nontranslated Finnish literature was the Finnish version of J. D. Salinger's The Catcher in the Rye (1951), translated by Pentti Saarikoski (Sieppari ruispellossa 1961), which we will discuss later.

The relationship between translated and domestic literature is complex because these two types of literature are not coherent systems but consist of different parts (genres). To give an example, the position of translated young-adult literature seems to be more central than that of adult fiction because the vast majority of young-adult books published are translations. It should be noted that the notion of a system is theoretical; that is, systems have no ontological status (Hermans 1999: 103). Moreover, the whole concept of a system has been criticized by the translation scholar Anthony Pym (1998: 115-124) because of its obscurity; he suspects that it reflects the human tendency to see things as systematically organized rather than being indicative of a reality organized in systems. For our purpose, however, the concept is a suitable framework because we are interested in the norms guiding literary translations, which presumably differ in various literary genres. In addition, we are interested in discovering how translated literature influences domestic literature and vice versa. Nevertheless, it should be noted that, as Even-Zohar (1990 [1979]) points out, the stratification of the polysystem is dynamic, the subsystems are not homogenous and they partly overlap. 


\section{Data and methods}

The corpus underlying the study of Tiittula and Nuolijärvi (2013) consists of 200 literary works, of which 106 titles are original Finnish literature and 94 are translated books; an original and its translations being counted as one work. 17 of the titles have been translated twice or several times into Finnish. The source languages of the translated works are English (51), Swedish (21), German (13), French (5), and Russian, Estonian, Czech, Norwegian (1 each). The selected novels were published during a period of 130 years, from the late $19^{\text {th }}$ century to the beginning of the 2000s. These works were selected because of the spoken language variation in their source texts. The selection includes both well-known and popular works and also less known or forgotten works that are interesting from the perspective of the research task.

The data represent various genres: literary fiction, young-adult fiction, as well as genre fiction, in this case romance and crime. We are fully aware of the problematic nature of this classification: the outlines of the categories cannot be clearly defined, a work can be placed in different genres and its position can change. Nevertheless, we have used this classification because of its relevance to the study of spoken language variation, as we wished to discover whether there are differences in language use according to content and audience. For example, how does young-adult fiction linguistically represent the lives of young people and their interaction, or crime fiction the fact that some characters are criminals?

The focus of the study lies in the intersection of several fields: Translation, literature, and (spoken) language. Accordingly, we have combined approaches from the corresponding disciplines, especially from translation studies and linguistics; literary studies and the history of literature, in contrast, provide a relevant background. The analysis focuses on different linguistic varieties, as well as on the illusion of speech created in literature, which we have examined from the perspective of sociolinguistic variation and dialogicity. By dialogicity we mean the interaction of characters as expressed in dialogues and studied with the methods of conversation analysis.

Regarding the translation aspect of the study, our research can be positioned within descriptive translation studies, where translations are seen as products of the target culture and where the concept of norms has played a central role, for example in the search for explanations why translations differ across time and culture (see e.g. Schäffner 1999). Norms regulate social activities, including translating, and decisions on what and how to translate are not only made by translators; other actors, such as publishing editors, readers and reviewers must also be taken into account, as must the social and cultural contexts in which these persons act. For the study of these factors, ethnographic methods are relevant; in addition to translations, we have examined literary reviews, articles and discussions on translations, and we have interviewed publishing editors in order to reveal attitudes towards spoken language representations and what are regarded as acceptable or "good" translations. 
Our study of norms and their changes is, in many respects, comparative. We contrast a) domestic (original Finnish) literature and translated literature; b) different literary genres: adult vs. young-adult fiction; literary fiction ("high literature") vs. genre fiction ("popular literature"); c) texts from different eras, including retranslations. The contrastive approach allows us to examine how norms have changed across genres and in the subsystems of the system of Finnish literature, and whether a development in one system has had an impact on the other.

\section{Translating colloquial language}

Translating literary representations of speech is challenging because the features of spoken language vary across languages and occur on all linguistic levels. The conventions of representing speech in writing also differ in various cultures. Moreover, varieties of spoken language carry certain connotations and reflect cultural and social values. It has been claimed that the translation of dialects and other kinds of intralinguistic variation is impossible (e.g. House 1973) because they are strongly associated with concrete places and their inhabitants, and can evoke further connotations that cannot be reproduced in the target language. Nevertheless, dialects have indeed been translated, and also with success. However, many studies indicate that non-standard spoken language tends to diminish or even disappear when a source text containing colloquial language is translated. Although this may arise from literary traditions and may have culture-specific explanations (for an example of the Hebrew case, see Ben-Shahar 1994), general tendencies, so-called translation universals (Baker 1993), have also been put forward. In this section, we discuss general tendencies, as well as the translation strategies generally available and used.

\subsection{Translation universals}

Translation universals are general tendencies that are assumed to appear in the translation process across texts, languages and cultures, independent of the language pairs in question, whereas norms, which we will discuss in section 5, define what is regarded as acceptable in a given culture and time. In translation studies, various translation universals have been hypothesized (cf. Mauranen \& Kujamäki 2004); of these at least the hypotheses of standardization/ normalization, explicitation and repetition avoidance are relevant to the translations of texts with non-standard spoken varieties.

The assumption that translations tend to be more normative or conventional and show less linguistic variation than comparable non-translated texts has been proposed under various notions (standardization, conventionalization, simplification, normalization) with varying foci. We use the terms standardization and normalization with reference to the tendency of translations to render nonstandard spoken language varieties into standard language. In this respect they can be viewed as the S-universals ( $\mathrm{S}$ for source) suggested by Chesterman (2004: 39): they predict the difference between the source text and the target text. However, they can also be seen from the angle of the target culture if we 
examine how the translator uses the target language and compare dialogues in original Finnish novels with translations, which would suggest that they be assigned to Chesterman's T-universals (T for target).

The notion of standardization stems from Toury (1995), who introduced "the law of growing standardization". This means that in translations more habitual or established options are favoured over more experimental or unusual choices. What is both interesting and relevant for our study is the connection between theories of standardization and the status of translations within Even-Zohar's polysystem theory (1990 [1979]), mentioned above. Toury (1995: 271) has suggested that "the more peripheral this status, the more translation will accommodate itself to established models and repertoires", and he further remarks that "only when centrality is assigned to translating and/or translations will the law show signs of cracking" (italics in original).

The normalization of dialect has been examined by Englund Dimitrova (1997), who hypothesized that any shift in translation will tend to move towards the right on a continuum from strongly marked spoken language varieties (left) through less marked language towards marked written/elevated language (ibid. 63). For example, according to this hypothesis, a variety of general regional or rural origin would shift towards a variety with a specific social origin, whereas marked colloquial language would shift towards neutral language.

The explicitation hypothesis (Blum-Kulka 1986) predicts that translators tend to make the target text more explicit than the source text. When translating spoken language, they may, for example, add cohesive devices such as connectives, complete elliptical utterances (Schwitalla \& Tiittula 2009) and fill the kinds of gaps typical of authentic speech, making the text more coherent and less context-bound (Ben-Shahar 1994: 199). Ben-Shahar (1994) claims that translators tend to focus on the linguistic material of the text, mainly on its referential function, which results in a loss at the pragmatic level.

The tendency to reduce repetitions, which has been regarded as one of the most pervasive universals of translations (Ben-Ari 1992: 223), particularly concerns translations of spontaneous speech, where repetitions abound. Since repetitions are typical features of spoken language, where they serve several functions, the avoidance of repetitions reduces the illusion of orality (Tiittula 2014). Avoiding repetitions can be explained by norms guiding translational behaviour, whereas other universals can be explained on cognitive grounds (e.g. under-representation of features unique to the target language: Malmkjær 2008; Tirkkonen-Condit 2004).

\subsection{Translation strategies}

There are several possibilities for translating a text with spoken language features. Ramos Pinto (2009) presents a model comprising a typology of strategies, which she divides into two main categories: linguistic variation preserving and non-preserving. Preserving strategies are further divided 
according to whether space and/or time coordinates are maintained. For example, translating into a target language dialect would re-allocate the plot to the target culture, whereas the use of a standard variety with the addition of meta-communicative comments on the language variety or the use of features from different non-standard varieties would help preserve the place coordinate. The translator can also render standard language speech into non-standard (cf. Findlay's examples of drama translations into Scottish dialects; 2000), which, according to Ramos Pinto's model, would be a non-preserving strategy.

In our study, we identified the following global strategies in the translation of dialects: 1) translation into the standard variety; 2) use of but a few features of spoken language, typically lexical or widely used morpho-syntactic features; 3) translation into a less marked colloquial variety; 4) translation into a target language dialect; 5 ) use of an artificial variety consisting of features from different dialects. In addition to these strategies, Czennia (2004: 510) mentions substitution with a sociolect or idiolect of the target language.

Translations seem to rely heavily on lexis when rendering spoken language features. Many studies indicate that translators prefer lexical means for creating the illusion of spoken language, whereas the writers of original texts make more varied use of different linguistic levels (Larsson 1992; Ben-Shahar 1994; Brodovich 1997; Nevalainen 2004; Schwitalla \& Tiittula 2009). The risk of solely using this one means is that the style of the target text becomes inconsistent, as it is lexically colloquial but grammatically standard or even hypercorrect, which, of course, may be an intentional strategy in order to make visible the translation as a hybrid form.

The use of variation is always meaningful in literature, and its flattening has consequences. Nevertheless, although the translation of linguistic variation into a standard variety probably changes the characterization of the characters and their relationship, it does not necessarily result in a loss of the illusion of speech, as it can also be created by other means, such as syntactic and dialogic devices or phrases typical of oral communication (e.g. short or elliptic sentences and interjections).

\section{Reconstructing norms}

The regularities observed in translations may be due to universals or norms. Both concepts are thus used in the search for explanations of the qualities of translated texts. Whereas universals imply invariable behaviour, norms help us understand the variability of behaviour, for example the existence of different translations of the same source text. According to Toury (1995: 61), norms determine the equivalence between a translation and its source text. Chesterman (2006) distinguishes between two notions of norms: a descriptive notion which defines a norm as a tendency, and a causal notion according to which norms affect behaviour, defining what is correct and acceptable. It is in this latter sense that norms have been used in most descriptive translation studies (Chesterman 2006: 14). 


\subsection{Norms in this study}

If we assume that norms regulate translations and wish to identify them at different periods of time, we must take into consideration the different kinds of norms: 1) linguistic norms (what is regarded as correct use of language, or standard vs. non-standard; attitudes towards spoken varieties); 2) literary norms (the conventions for representing speech in writing; what is acceptable, expected and typical in the genre and the literal polysystem); 3) social norms (for example, how foreigners can be described); 4) translational norms (what is regarded as a good translation); and, finally, 5) all these norms both in the source and target culture at a certain point in time. As Ben-Shahar (1994: 200) notes, the feeling of authenticity evoked in the reader by the text depends, to a great extent, on literary and linguistic norms, as well as reader habits, and is therefore time-dependent. Even though we have distinguished different norms, the difficulty of separating translational norms from other norms in the analysis of translations should be noted (cf. Paloposki 2002: 127).

Norms offer uniform solutions for similar problems and thus delimit variation. They define the kind of target text that is acceptable in each time period, culture and situation and specify the relationship between source and target text. As Toury (1980: 116) observes, the norms of the target culture may differ from the norms of the source culture. For example, slang might be used in the literary texts of the source culture but be unacceptable in the target culture. Norms can also be system bound (e.g. Hermans 1991: 164): We have found that the norms of translating colloquial speech in young-adult fiction differ from norms of translating speech in literary fiction.

In our study, the main source for norms is the corpus of translated and nontranslated texts, and the focus of the following sections lies in their linguistic analysis. In addition, we studied literature reviews, articles in which translators describe their translation strategies, and the criteria for Finnish prizes awarded for outstanding translations or translators; moreover, we also interviewed publishing editors. As Toury (1995: 65-66) notes, statements about norms are not the same as the underlying norms themselves, but they can be clues to underlying values (see also Paloposki 2002: 121). In the statements examined in this study, we found competing norms: translation prizes were often given to works in which the rich variation in the source texts was retained, whereas the interviews with publishing editors provided a more heterogeneous picture, as most of them tended to limit the use of spoken language, while others saw no problems in its use. The key question seemed to be the experience and skill of the translator. In literature reviews of newspapers, the language of translations seldom drew comment. Nevertheless, we found some instances where the use of colloquial or dialectal words was criticized. For reasons of space, it is impossible to explore the norm statements in more detail here. 


\subsection{The case of The Adventures of Huckleberry Finn}

The norms of a given culture vary across time, according to attitudes towards spoken language varieties in the language community. These attitudes also seem to affect the literary language and the representation of spoken language in fiction. In this section, we provide an example of how Finnish translators of the same source text have created the illusion of speech at different times.

The novel selected is Mark Twain's The Adventures of Huckleberry Finn (1884), which has been translated into Finnish five times. The first translation, published in 1904, was by Tyko Hagman, a well-known children's writer. The second version was translated by an experienced translator, Yrjö Kivimies, in 1927. The third translator is anonymous; the book was published 1936 in Petrozavodsk in Russian Karelia. This translation is shorter than the original book, and the translated parts resemble, almost word-for-word, the translation by Kivimies. The next translation, made in 1945 by Kirsti Laipio, is also a shortened version. The latest translation, by the poet Jarkko Laine, is from 1972. As is often the case, each translation was published by a different publishing house, demonstrating the competition between publishers for translations.

The most interesting spoken varieties in The Adventures of Huckleberry Finn are found in Huck's and Jim's speeches. Huck is the novel's first-person narrator, and his voice is dominant. In the original book, Huck's variety of English can be regarded as the 'norm' from which other dialects, to varying degrees, depart (Carkeet 1979: 316). According to Berthele (2000), who has analysed German translations of the novel, Huck's speech is a quasi-standard variety inside the fictional world of the novel. In the Finnish translations, Huck's dialect is rendered in standard language by Kivimies, the anonymous translator and Laipio. However, in the first and last translations, Huck's speech is represented by widely used variants of spoken Finnish, for example Laine utilizes incongruous forms in the third person pl. (ne vaati, in standard Finnish ne vaativat 'they demand+past tense+3. pers. pl.'), passive forms in first person pl. (me ruvettiin 'we start+passiv past tense', in standard Finnish me rupesimme 'we start+ past tense +1 . pers. pl).

In the source text, Huck's speech differs from Jim's, which represents African American English in Missouri. Carkeet (1979: 317) observes that Jim's speech has many features of the eye dialect, i.e. non-standard spellings for standard pronunciations, such as uv 'of'. Thus, the speech of Huck and Jim differs phonologically (as represented in spelling differences). In translations into different languages, Jims' speech, and accordingly the difference between the characters, has been represented in many ways. For example, earlier German translators rendered Jim's speech as pidgin-like learner German, thus representing him as unable to speak the language properly. Later German translators tried to avoid this kind of negative representation and instead used, for example, a Berlin subculture dialect, Saxonian dialect, Yiddish or Swiss German. These solutions, however, add other social connotations to the language (Berthele 2000: 607-8). In an old French translation (from 1886), Jim is neither an elder nor a person of authority but a ridiculous servant with low 
status; linguistically, this is marked by such features as Jim's and Huck's asymmetrical use of forms of address, such as the familiar tu and formal vous for 'you' (Lavoie 2002; 2007).

The Finnish translators arrived at different solutions for Jim's dialect, which reflect changing attitudes towards minorities over time in the community. Table 1 summarizes the use of spoken variants in different translations. The features are mainly situated at the phonological and morpho-syntactic levels or lexical level.

\begin{tabular}{|c|c|c|c|c|c|}
\hline Spoken language variants & $\begin{array}{l}\text { Hagman } \\
1904\end{array}$ & $\begin{array}{l}\text { Kivimies } \\
1927\end{array}$ & $\begin{array}{l}\text { Anonymous } \\
1936\end{array}$ & $\begin{array}{l}\text { Laipio } \\
1945\end{array}$ & $\begin{array}{l}\text { Laine } \\
1972\end{array}$ \\
\hline $\begin{array}{l}\text { Forms deviating from the } \\
\text { standard } d \text { : meirän (in standard } \\
\text { meidän) 'our' }\end{array}$ & $x$ & & & & $x$ \\
\hline $\begin{array}{l}\text { Forms deviating from the } \\
\text { standard ts: mettä (in standard } \\
\text { metsä) 'forest' }\end{array}$ & $x$ & & & & \\
\hline $\begin{array}{l}\text { Forms deviating from the } \\
\text { standard iA: sellasii (in standard } \\
\text { sellaisia) 'such' }\end{array}$ & & & & & $x$ \\
\hline $\begin{array}{l}\text { First pers. sg. pronoun: mä (in } \\
\text { standard minä) 'l' }\end{array}$ & & & & & $x$ \\
\hline $\begin{array}{l}\text { Apocope of } A \text { : talos (in standard } \\
\text { talossa) 'in the house' }\end{array}$ & $x$ & & & & $x$ \\
\hline $\begin{array}{l}\text { Apocope of } I \text { : näk (in standard } \\
\text { näki) '(she) saw' }\end{array}$ & $x$ & & & & $x$ \\
\hline $\begin{array}{l}\text { Apocope of } n: \text { nii (in standard } \\
\text { niin) 'so' }\end{array}$ & $x$ & $x$ & & $x$ & $x$ \\
\hline $\begin{array}{l}\text { Opening of diphthongs: tiätää } \\
\text { (in standard tietää) 'to know' }\end{array}$ & & & & & $x$ \\
\hline $\begin{array}{l}\text { Third pers. pl. incongruence: ne } \\
\text { tekee (in standard he tekevät) } \\
\text { 'they do' }\end{array}$ & $x$ & & & & $x$ \\
\hline $\begin{array}{l}\text { No diphthongs in unstressed } \\
\text { syllables: punanen (in standard } \\
\text { punainen) 'red' }\end{array}$ & $x$ & $x$ & & & $x$ \\
\hline $\begin{array}{l}\text { Primary gemination: sannoo (in } \\
\text { standard sanoa) 'to say' }\end{array}$ & $x$ & & & & $x$ \\
\hline
\end{tabular}




\begin{tabular}{|c|c|c|c|c|c|}
\hline $\begin{array}{l}\text { Past participle active: ollu (in } \\
\text { standard ollut) 'been' }\end{array}$ & $x$ & & & & $x$ \\
\hline $\begin{array}{l}\text { Epenthetic vowel: kylymä (in } \\
\text { standard kylmä) 'cold' }\end{array}$ & $x$ & & & & \\
\hline Dialectal words & $x$ & & & & $x$ \\
\hline $\begin{array}{l}\text { Infinitive instead of an inflected } \\
\text { finite form: minä mennä (in } \\
\text { standard menen) 'I go' }\end{array}$ & & $x$ & & $x$ & \\
\hline $\begin{array}{l}\text { Nominative instead of other } \\
\text { cases }\end{array}$ & & $x$ & & $x$ & \\
\hline $\begin{array}{l}\text { Short vowel instead of a long } \\
\text { one: mene (in standard menee) } \\
\text { '(she) goes' }\end{array}$ & & $x$ & & $x$ & \\
\hline Feature group & $A$ & $b$ & c & $b$ & $a$ \\
\hline
\end{tabular}

Table 1: Finnish translations and their use of colloquial variants for Jim's speech. If a translation exploits a certain feature it is marked with ' $x$ ' in the corresponding column.

Regarding the language features of Jim's speech, the Finnish translations can be classified into three groups: a) those employing features of western or southwestern Finnish dialects (the first and the last translation); b) those representing Jim's speech as that of a non-native speaker (the versions from 1927 and 1945 ); and c) those void of spoken language features (the translation from 1936).

In Hagman's translation (1904), Jim's dialect represents widely used variants in western Finnish dialects, especially the Häme dialect. In Laine's translation, which was published in 1972, almost 70 years after the first translation, Jim's speech represents the southwest Finnish dialect spoken, for instance, in Turku. The dialects differ slightly, but in both translations Jim speaks a regional variety of Finnish, characterizing him as a native speaker. In the versions from 1927 and 1945, rather than a local Finnish dialect, Jim speaks a form of Finnish stereotypical of non-native speakers. As Table 1 shows, the features of Jim's speech in these translations are totally different from those in translations using a regional dialect. The translation from 1936, published in Petrozavodsk in Russian Karelia, is a case apart. Jim speaks standard Finnish but talks about himself in the third person, using his own name as children do: Jim kuuli 'Jim heard', hän haukkui Jimiä aina 'she always shouted at Jim'.

The spoken variety selected in the translations has an impact on the characterization of the characters and their relationship. In each version, Jim's speech illustrates how the translator and the language community distinguish black people from white, slaves from the free: dialect vs. standard; non-native vs. native speech. 


\section{Changing translation strategies across genres}

In the following, Finnish translation tendencies over the course of one century are studied in different genres, and the use of spoken language in literature is presented through examination of literary fiction, young-adult fiction and genre fiction, including romantic novels and crime fiction.

\subsection{Literary fiction}

Finnish literary translations can be placed into three groups according to their date of publication: 1) early translations from the 1800s until 1920 (this era is considered the "translation period" of Finnish literary fiction (Kovala 1992: 29)); 2) translations published from the 1920 s to the end of 1950 s (at this time the number of translated works of literary fiction was lower than that of domestic, non-translated literature; for example, in 1950 only 31.6 per cent of published books were translations); 3) translations from the 1960s until today (in the 1960s the use of spoken language varieties expanded, a trend which continues today).

In the 1800s, translated fiction served to elaborate both Finnish literary and linguistic models (Paloposki 2002: 123). The early stage of emerging standard Finnish and the discussion of its dialectal base are reflected in the language of translations. For instance, the translator could adopt the model of Old Literary Finnish or make use of his or her own dialect (Paloposki 2007). Translators were typically either famous authors, researchers of Finnish language or teachers. Since standard Finnish had not yet been established, less attention was paid to source text fidelity than in later periods. According to Paloposki, some of the early translations were literal, others more or less adapted versions. Throughout the $19^{\text {th }}$ century the central aim were free and "fresh sounding" Finnish translations. It was not until the early 1900 s that more fidelity to the source text was required (Paloposki 2007: 122).

One of the earliest novels in Finnish translation was Charles Dickens' and Wilkie Collins' No Thoroughfare (1867), translated by O. G. C. ${ }^{1}$ in 1870 as IIman menestyksettä! Joulukertomus. The language is standard Finnish, and the target text seems to be formally very close to the source text. Nevertheless, many of the foreign-sounding structures were typical of written Finnish prose of the time - which was possibly affected by interference from translations. Despite displaying features of written language, there are signs that the translator attempted to create an illusion of speech, such as the presence of particles typical of spoken dialogue. These particles are, among other things, used for the structuring of interaction, and they function as turn-taking devices and connect turns (e.g. Yes? $\rightarrow$ Noh, ja sitten? 'well, and then?').

The German writer Fritz Reuter was very popular in Finland at the turn of the $19^{\text {th }}$ century, so much so that his works were translated several times. He wrote in Low German, and the texts contained colloquial features on many levels,

\footnotetext{
${ }^{1}$ Acronym of Otto Georg Calamnius (Kallio 1939).
} 
including the loss of certain sounds. Nevertheless, his novels were rendered into standard Finnish, with the language resembling that used in original Finnish works. However, dialogue was often translated quite freely, with speech indicated by various particles, such as dialogue particles and clitics, the latter of which are typical of Finnish (e.g. mitähän 'what+clit.part'²). In addition, mild expletives (e.g. Saakeli soikoon! 'damn it') were also used. One translator, the well-known writer Joel Lehtonen, took many liberties by omitting passages and adding expressions in his 1913 translation of Ut mine Stromtid (1862), titled Maamiesajoiltani. In the dialogue sections, he used features of the Finnish Eastern dialect and even created his own words.

In this context, another Finnish writer worthy of note is IImari Calamnius-Kianto who translated Oblomov (1859), by the Russian author Ivan Goncharov - the Finnish translation appearing in 1908 under the title Herra Oblómov ('Mr Oblomov'). The source text is standard language, but it contains typical features of authentic dialogue. In his translations, Calamnius-Kianto, like Lehtonen, uses features of the eastern Finnish dialect, for example diverse dialectal syntactic and phraseological features, as well as dialogue particles and clitics. The illusion of speech is evoked by connecting turns with dialogue particles and repetitions; also pronouns and proadverbs are frequently used, for example Missähän lie koko nenäliina? - Ka tuollahan tuo on. 'Where+clitic particle might the whole handkerchief be? - Well over there+clitic particle that is'. It is interesting to note that the two later translations of Oblomov exhibit less spoken language features.

Our corpus indicates that until the 1920s Finnish translators seldom made use of devices imitating the phonological and morphologic features of spoken language, although these occurred in original Finnish literary texts. The illusion of authentic speech was achieved - if at all - through dialogue features, such as Finnish turn taking conventions, and the use of various particles, especially clitic modal particles. In terms of lexical means, the use of expletives was not uncommon. There was no evidence of the use of a special translation strategy: Some translators would translate quite freely, while others remained very close to the structures and forms of the source texts. Furthermore, there was variation within the work of single translators.

In the early $20^{\text {th }}$ century, as standard Finnish became established, dialogue in non-translated original Finnish literature became more linguistically standardized, and the same tendency can be observed in translations in the first half of the 1900s: The social differences characterized in the source text were rarely represented in the target text. A good example is Thomas Mann's Buddenbrooks (1901), which was translated by Siiri Siegberg in 1925 as Buddenbrookit. In the source text, the social and regional differentiation of characters is depicted through their speech: The consul family speaks standard German, in contrast to their servants and workers, who use Low German, which the old consul also uses when addressing his striking workers. The crude

\footnotetext{
${ }^{2}$ The Finnish clitic $-h A n$ is difficult to define as it has several context-dependent meanings, but is somewhat comparable to the German ja
} 
salesman Permaneder, who comes from the very different culture of Southern Germany, speaks in Bavarian dialect, which to the consul family is as odd as the lout himself. However, in the translation, all the characters speak standard Finnish; the only hint of a character having a lower social status is in the speech of a maid, who uses the demonstrative pronoun se 'it' instead of the personal pronoun hän 'he'. In 2010 the novel was retranslated by llona Nykyri, who retained the original linguistic variation and rendered such varieties of German as Bavarian into a mixture of Ostrobothnian and far-northern dialects and Low German into the southwest dialect spoken in Turku, that is, the setting of the novel is relocated from the old Hansa town of Lübeck to an old Finnish market town.

The use of standard language in the translations of source texts where nonstandard speech is remarked upon or addressed by the characters themselves can result in omissions, as demonstrated by Aune Brotherus's 1946 Finnish translation of George Eliot's Adam Bede (original 1859), which was titled Rehdin miehen rakkaus 'The Upright Man's Love'. In the following extract an innkeeper, Mr Carson, shows his superiority vis-a-vis the local inhabitants through his manner of speech. The contradiction between the language and the content of his speech induces irony in the source text but is lost in translation, due to the standard language. The passage where the character quotes the local people's way of speaking (marked in bold) is omitted in the Finnish translation:

"[--] I'm not this countryman, you may tell by my tongue, sir. They're cur'ous talkers i' this country, sir; the gentry's hard work to hunderstand 'em. I was brought hup among the gentry, sir, an' got the turn o' their tongue when I was a bye. Why, what do you think the folks here says for 'hevn't you?'-the gentry, you know, says, 'hevn't you' - well, the people about here says 'hanna yey.' It's what they call the dileck as is spoke hereabout, sir. That's what I've heared Squire Donnithorne say many a time; it's the dileck, says he." (Eliot: Adam Bede 2010 [1859], Ch 2.)

Although the language in novels, both non-translated and translated, was mostly standard Finnish between 1920 and 1960, there were also exceptions, such as the translation of August Strindberg's Röda rummet (1879), which was one of the earliest Swedish novels representing spoken varieties - mostly through lexical means (Lindqvist 1995: 84). The novel was translated into Finnish in 1939 by the renowned poet Viljo Kajava, who gave it the title of Punainen huone. His rendering was quite close to the source text, with similar stylistic variation in the lexical choices, which gave the characters the same sound as in Strindberg's work. The author and the translator both make use of lexical and interactional devices (such as repetitions and terms of address) to create the illusion of speech as well as to demonstrate the social differences between the characters, differences which in some instances are also depicted by phonological and morphological means. An interesting case is a letter written by an unschooled young woman, which combines written literary style with features of spoken language, such as dropped consonants and vowels and colloquial words. It is interesting that at a time when spoken language varieties were rarely used in the literature, the characteristics of non-standard speech occur in a passage 
representing written text. Through the use of spoken language features, the young woman is portrayed as being unfamiliar with the norms of written language.

In original Finnish literature, varieties of spoken language began to occur more frequently in the 1950s and 1960s. In the translations of this period, the use of colloquial features can also be occasionally observed. This use was, however, unsystematic, as the 1954 translation of Charles Dickens' Oliver Twist (1837-39) illustrates. The novel has been translated into Finnish several times, the 1954 translation by Maini Palosuo being the $4^{\text {th }}$ version. In this translation, colloquial features occur in many instances, albeit to a far lesser degree than in the original. Moreover, some characters use both dialect and standard Finnish, although in the source text their language variety is dialectal at all times. Nevertheless, the change towards more colloquially marked language is clear, compared to the earlier translations, which were entirely in standard Finnish.

A pioneering work was Pentti Saarikoski's 1961 translation of J. D. Salinger's The Catcher in the Rye (1951), titled Sieppari ruispellossa in Finnish. Saarikoski was a writer and a poet who translated from many languages. The translation of Salinger's novel received much attention because of the use of slang, which differed in many respects from the variety employed by Salinger and was the result of Saarikoski's attendance at numerous parties and cafés in Helsinki, where he listened to how teenagers spoke (Tarkka 1996: 2). A word list with explanations was attached in the translation, which indicates how rare the literary use of slang was. Today, some of those words are outdated but others are still in common use. Features of slang occurred at every linguistic level, not only in dialogues but also in the narration. The translation's reception was mixed. It was praised as enjoyable and pioneering, said to be representative of new youth and its language, and the popularity of the book was also considered to be based on its language. However, it also attracted disapproval because it was one of the first books to use Helsinki slang to such a great extent. Nevertheless, Saarikoski's translation attained cult status, which encouraged other Finnish authors to use slang in their novels.

Since the 1970s the use of spoken language has strongly increased in original Finnish literature, and Finnish authors make use of diverse language varieties when describing different milieus and characters. Moreover, spoken language is used not only in dialogue but also in narration. The expansion of linguistic variation has also offered fruitful ground for the use of spoken varieties in translations. At the end of the $20^{\text {th }}$ century, such translations were no longer uncommon, with dialogue featuring ever more colloquial language. Although a tendency towards normalization can still be observed, today there are many translators who fully render the linguistic variation of the source texts by utilizing the resources of the target language.

One such translator is Oili Suominen, who has translated most of Günter Grass' novels into Finnish. She argues that a translator must identify all the typical features used by the author and then create a text with similar features in the target language; if the author has used dialects, the translator must also render 
the text into a non-standard variety, but it must be highly stylized, perhaps merely resembling a dialect (Suominen 2005). For example, in the novel Unkenrufe (original 1992, Finnish translation Kellosammakon huuto 1992), the Polish character Alexandra Piątkowska is a non-native speaker of German who uses non-standard grammatical constructions typical of language learners, such as the deviant use of articles and word order in subordinate clauses. The Finnish grammatical system has no articles, and word order is quite free. In contrast, however, the object case causes difficulties for language learners, as it thus does for Piątkowska in the Finnish translation. In addition, article errors in the source text are substituted with verb omissions in the target text. Another of the novel's main characters is a German professor, Alexander Reschke, whose language is elevated High German, which is rendered into an equivalent standard Finnish variety. The scene of the story is Gdansk, where one of the characters is Erna Brakup, a near 90-year-old German-born woman who speaks a patois of the pre-war period. This dying German dialect is described in the novel and recorded by Reschke, hence it is important and cannot be rendered into standard language. Suominen's solution is a strong western Finnish dialect, which is, however, a hybrid of local dialects and cannot be strictly located. In addition, the novel features a young German student who speaks non-regional colloquial language, which is rendered into colloquial Finnish; neither the German nor the Finnish variety contains dialectal markers.

Another example of rich variation is Marjaneh Bakhtiari's novel Kalla det vad fan du vill (2005) and its Finnish translation, Mistään kotosin (2007), by Leena Peltomaa (see also Simo Määttä's article in this special issue). In the Swedish original the main characters are Iranian born immigrants whose mother tongue is Farsi, which interferes with their Swedish, with the exception of the younger generation's language. Accordingly, spoken varieties play an important role in the characterization of the novel's characters. In the original, the speech of the Iranian parents is marked to indicate that they speak Swedish with an accent; in the Finnish translation their non-standard variety is rendered more through grammar, but it also contains markers imitating a foreign accent; the solution is credible, since an accent is more stable than many other learner language features. Both in the original and in the translation, the accent is expressed through spelling. In Finnish, for example, gemination and long vowels typically cause difficulties, of which the translator makes use (Miksi teilä [= teillä] on joulupuki [= joulupukki] ? Eihän sielä [= siellä] ollut mitän [= mitään] pukia [= pukkia] kun Jesus [= Jeesus] syntyi! 'Why do you have a Santa Claus? There was no Santa Claus over there as Jesus was born!'). The pronunciation of Swedish is difficult for the Iranians, but so are Farsi names for Swedes - as well as for Finns. Moreover, in the novel their English carries a Swedish or Finnish accent respectively, in contrast to the Iranians' native-like English. In both source and target text, the young people use colloquial language or slang. The characters' use of non-standard language often contrasts with the cultivated content of their speech: The Iranian mother, Panthea, is a scholar, the father, Amir, a former poet and publisher, and their educated world clashes with the mundane topics of their new environment. Hence, linguistic variation is an integral part of the novel. 
The translation of Bakhtiari's novel can be regarded as a pioneering work, as for the first time in Finnish literature immigrants are given a voice of their own which is neither a deficient form nor a regional dialect of Finnish but instead simulates authentic code-switching. This can be contrasted to the parallel case of the translation of Jonas Hassen Khemir's Ett öga rött, which appeared a few years earlier (2004), where no features of immigrant language can be found, although the Swedish source text gained much attention in Sweden just because of its use of such language (see also Simo Määttä's article in this special issue). Thus, Peltomaa's translation, like Saarikoski's translation of Salinger's The Catcher in the Rye, could become a forerunner that also provides a model for non-translated Finnish literature.

\subsection{Young-adult fiction}

In young-adult fiction, translations have played a central role throughout the history of Finnish literature. In 2006, 76 per cent of published young-adult books were translations; although their share has subsequently diminished and was 55 per cent in 2015 (Finnish Book Publishers Association 2016). The high proportion of translations indicates their central position in this part of the Finnish literary system compared to adult literary fiction, where around half the published works are translations today.

In the late 1800 s and early 1900 s, many popular young-adult books by famous writers (such as Robert Louis Stevenson, Jules Verne, Louisa M. Alcott, L.M. Montgomery and Frances Hodgson Burnett) were published in Finnish translation. However, in the Finnish versions the dialogue seldom featured colloquial elements. Books for girls, in particular, were translated into 'correct' language - a tendency that still prevails in the new translations of those works. The language of the translations was mostly standard Finnish, with the rare exception of Friday's speech in the translations of Defoe's Robinson Crusoe (1719), where his speech was rendered as defective learner language (the first direct translation was made by Samuli S[uomalainen] and published 1905). Mark Twain's character Jim, whose speech was also later translated into learner language, spoke standard Finnish in the first translation of The Adventures of Tom Sawyer (1876; translated by Joosua Weisell using the pseudonym -a -II as Tom Sawyer: koulupojan historia 'a schoolboy's history' 1879), whereas in the second translation (Tom Sawyerin seikkailut, by an anonymous translator 1909) his speech was colloquially marked, singling him out from the other characters, who spoke standard language. A significant exception to the usual strategy of translating into standard language was Tyko Hagman's translation of The Adventures of Huckleberry Finn (1904), as described in section 5.2.

In the early 1900 s, typical markers of speech - when used at all - were expletives (e.g. hitto soikoon 'damn it'), dialogue particles and interjections, although some colloquial words could also occur. In some works, Finnish dialects were used to mark a character as somehow deviating from the other figures in the novel. For example, in I. K. Inha's translation of Rolf in the Woods (1911; Rolf salolla 1914), both the young boys and the American Indian Kuanab 
(in the source text Quanab) speak standard Finnish, whereas the Dutch trader uses a form of Rauma (southwest) dialect. In Hederspojkar (1925), by the Swedish author Ebbe Lieberath, one of the young characters comes from another district and speaks an urban variety of western Swedish, indicating his lower social class. In the 1928 Finnish translation, Kunnon poikia, by Väinö Nyman, his speech was rendered into Savo (eastern Finnish) dialect, which distinguishes him from the other young characters, who speak 'normally', i.e. standard Finnish. The third example is Ethel Turner's Miss Bobbie (1897): In Aune Ståhlberg's 1936 translation, Bobby koulitaan pojaksi ('Bobby is moulded into a boy'), all the children speak standard language with the exception of the family's youngest son, whose speech is colloquially marked. In the source text the difference between his speech and that of the other children is not so remarkable, mostly concerning phonological differences, whereas in the target text his speech also differs with respect to the usage of colloquial pronoun variants. A later example comes from Enid Blyton's The Island of Adventure (1944), which was translated by Laila Järvinen as Seikkailujen saari in 1950. The only character whose speech is colloquially marked is the black servant JoJo: He differs from the others in terms of his colour, lower social status and morality, but the character, who turns out to be a scoundrel, is also distinguished by his speech.

The strategy described above for translating speech in young-adult books did not change significantly until the 1960 s, when the focus shifted to new, realistic novels and their translations. For example, 1961 saw the publication of Pentti Saarikoski's contentious translation of Salinger's The Catcher in the Rye; it was not actually a young-adult book, but as a story about adolescents, it was read by them nonetheless. However, while Saarikoski introduced slang into his translations, the dialogue in young-adult books remained predominantly standard language, with spoken varieties used to mark out a character from the others.

One of the earliest books with a rich use of slang was Marja Leskinen's translation of S. E. Hinton's The Outsiders (1967), titled Me kolme ja jengi 'We three and the gang' (1969). The narrator is a 14-year-old gang member, Ponyboy, who has grown up in a North-American metropolis. The illusion of authentic slang is created by several means, including the use of slang, colloquial forms of pronouns, and phonological and morphological features. Interestingly, three years later another Hinton book about the same gang of youngsters was rendered into standard language, indicating that the use of slang was not yet the norm. Nevertheless, the absence or infrequent use of colloquial language does not mean that orality was neglected, since other devices were employed, especially syntax and various particles, such as dialogue particles and modal particles.

Towards the end of the $20^{\text {th }}$ century, spoken language varieties were increasingly used in original Finnish literature. This tendency can also be seen in the translations of young-adult books dealing with difficult social issues, which was reflected in their language. The range of means for representing spoken language diversity has now broadened to include all linguistic levels from 
phonology to interactional features (such as dialogical repetitions). A good example is Swedish writer Mats Larsson's novel Axel Borell och rasisterna (1993), translated by Marja Kyrö as Alex Borell ja rasistit (1995). The narrator is Axel, a 15-year old resident of Stockholm, whose Chilean girlfriend is assaulted by skinheads. The speech of the young people in the novel is rendered into a youth variety of Finnish; the illusion of speech is constructed with particular reliance on phonological means, so that the reader can almost hear the characters speaking. What is important is the diversity of the varieties of Finnish used: Axel, the drunken skinheads, Axel's parents, and a publishing editor all speak differently. The illusion of authentic speech can be explained by the translator's strategy: She explained to us that she first attempts to imagine the appearance of the characters and how they speak and only then renders their speech into Finnish.

Since the 1990s, the use of spoken language varieties has been the norm in young-adult fiction and is no longer unusual or distinctive. However, this also means that the use of standard language can be a striking feature. Moreover, if young-adult books are translated from a literary culture in which colloquial language is not normally used, the translator may choose to render the speech of young characters, in particular, into slang. In our corpus this was the case with a book by Estonian author Aidi Vallik, which appeared in Finnish translation in 2002. Thus standardization does not apply to young-adult literature today, and with respect to this genre the whole normalization hypothesis can be questioned.

\subsection{Genre fiction}

To a great extent, genre fiction is international. In Finland the majority of genre fiction, i.e. romance and crime, has always been translations. The first translations were published as early as the late 1800 s, but the golden age of translated genre fiction was the 1920s. The number of Finnish translations increased rapidly, and they were read by a wide audience (Sevänen 2007: 14). In the following, we present some examples of romantic novels and crime fiction during the first and last decades of the $20^{\text {th }}$ century.

Romantic novels can be characterized as timeless and placeless (Niemi 1975: 68). Hence, it is possible for the reader to identify with the story and its characters because cultural features are less salient. 100 years ago, the romantic novels of Hedwig Courths-Mahler, Berta Ruck and Vicki Baum were very popular. The German author Hedwig Courths-Mahler was highly productive: She wrote more than 200 novels, 53 of which were translated into Finnish. The first translation into Finnish was published in 1918, the last in1927. Her themes were typically the basic elements in all romantic novels: Love, luck, sorrow and hate; bad people, who are really bad and good people who are really good (Eskola 2007: 369). It was common in the romantic literature of the time that every character used standard language in dialogue regardless of age, gender, social status, and occupation. 
During the last decades of the $20^{\text {th }}$ century, one of the most successful popular authors was Barbara Cartland, who wrote more than 700 novels, of which at least 125 have been translated into Finnish. One example is Love in the Clouds (1980), which appeared in Finnish in 1981 (Rakkaus asuu vuorilla, translated by Kaarina Jaatinen). As in most romantic novels, the language used by the characters is standard. Moreover, the young lovers also use a "correct" variety, and their dialogue is formal and stereotyped. Thus, the first romantic novels hardly differ from their later counterparts. For example, when examining the current romantic novels of Danielle Steel and Nora Roberts and their translations in Finnish, the same pattern can be observed. It is only in children's speech that a few spoken variants can be found. For example in Nora Roberts' novel Blue Smoke (2005) (translated by Anna Salo as Savuhuntu in 2007), children use variants common in spoken language in some instances: saadaanko me ('get+passiv pres.+questioning clitic we', 'do we get', in standard Finnish saammeko); sulta ('you+ablat.' 'from you', in standard Finnish sinulta). The same tendency to avoid spoken language features applies to original Finnish romantic novels.

Compared with translations of high literature and young-adult fiction, the language of romantic novels in Finnish translation has not changed over time; both today and in the past there is a complete lack of variation, as unrealistic content and unreal language varieties contribute to the construction of a coherent fantasy world.

Regarding crime fiction, most translations are from English, but novels are also translated from other languages, for example from German and French, and today from Swedish and Norwegian in particular. In the late 1800 s and early 1900s, some of the first authors of crime fiction in Finnish translations were Arthur Conan Doyle and Agatha Christie - both of whom remain popular today. Christie's Hercule Poirot and Miss Marple are perhaps, along with Doyle's Sherlock Holmes, the world's best-known fictional detectives. Sirkka Rapola's translation of Christie's novel Death on the Nile (1937) came out in Finland in 1940 under the title Kuolema Niilillä, and a new translation by Kirsti Kattelus was published in 1978, with the newest edition from 2008. The source text is dialogic, simulating orality. The turns are connected by repetitions, answering particles and conjunctions. The first translator used the same means, but the language is standard and less informal; moreover, Poirot's French idioms were domesticated and translated into Finnish. In contrast, in the retranslation by Kattelus, Poirot's use of French expressions is maintained; apart from these details, the language does not differ greatly between the translations.

The American author Sara Paretsky represents the new generation of crime fiction writers, and she has been a model for many authors around the world, also in Finland. Her books exhibit features of the hard-boiled crime fiction exemplified by the likes of Raymond Chandler, but a feminist emphasis is also appreciable. The main character and narrator is Vic(toria) I(figenia) Warshawski, a private investigator. The first novel to appear in Finnish was Osmo Saarinen's 1990 translation of Indemnity Only (1982), which was published under the title Sohaisu pimeään. The target text is mostly rendered into standard Finnish, with 
the exception of colloquial words, swear words and coarse phrases in the dialogue and in the narrator's discourse; these expressions describe the hard world of criminals and policemen. As is so often the case, the language in the book is predominantly the standard variety, only criminals and a young girl use spoken varieties. Hence, in crime fiction, it appears that spoken features are restricted to the lexical level.

To sum up, the use of spoken language features in translated crime fiction differs to some extent from that in romantic novels. However, in neither genre has the presentation of dialogue significantly changed during one hundred years. Linguistically, translated popular literature seems to highly correspond to what is viewed as standard and 'correct'. It can be assumed that the language of these genres conforms to reader expectations. As one of the publishing editors stated in our interviews: The audience of crime fiction is conservative and does not want to read texts in colloquial language.

\section{General tendencies}

Translated literature had a central status in the Finnish literary system in the late $19^{\text {th }}$ century and early $20^{\text {th }}$ century; nevertheless, its language was more standard, showing less variation than that of original Finnish works.

Subsequently, the norms for using colloquial variants in translations have changed, influenced by the literary and linguistic norms of original Finnish literature. Nonetheless, there are exceptions. For example, Helsinki slang was first used in a translation, which sparked its use in original Finnish works. The norms of different literary genres also vary: The language in romantic fiction has always been and remains more standard than in the other genres, and in the young-adult fiction of today, slang may be used even if the language of the source text is less colloquially marked. In spite of clear trends in the translation of speech and the norms influencing translations, the final decision is always made by the individual translator, which is why examples of rich, non-standard variation can also be found in translated works from earlier periods.

In our data we identified several general tendencies. Compared to original Finnish fiction, dialogue in translations tended to be rendered using more standard language, that is, it was less colloquially marked, a finding which confirms those of earlier studies (e.g. Englund Dimitrova 1997; Nevalainen 2004). In spite of the tendency towards normalization, in most cases orality was marked in some way. The most frequent devices used to create the illusion of speech were lexical elements (for example, swear words, particles), whereas phonological and morphological features were less exploited. Syntactic devices such as short or elliptic sentences were also used, although such tendencies as normalization, explication, and reduction of repetitions were also observed. Nevertheless, the trend in translated Finnish literature has been towards a broadening of the range of linguistic means employed, along with an increase in marked spoken features. Today, the number of translations utilizing devices at all linguistic levels is remarkable; in young-adult books this can even be regarded as the norm. 
The standardization of rural and social dialects results in the reduction or omission of differences between characters and may change their relationship. In the texts we examined, when colloquial language varieties were employed selectively in the target language, the characters were typically children and young adults, or this non-standard speech was used as a device for portraying the character as deviant in some way, for example as a drunk. We also found two further tendencies which led to the flattening of spoken language: 1) omission of features of the source language with no equivalent in the target language (e.g. subject omission is a colloquial feature in German but not in Finnish); 2.) under-use of typical spoken features of the target language (e.g. incongruent forms in Finnish, such as non-agreement between plural subjects and singular verb predicates), which may result from the absence of direct source language stimulus. In addition, both tendencies might stem from a faithful translation strategy concentrating on the transmission of forms.

The non-rendering of spoken language variation changes the style in comparison to the original novel and may also lead to other crucial changes. For example, it can result in a reduction of humour and a shift in the content focus. Moreover, irrespective of the global translation strategy, the way of translating orality and spoken language varieties always has consequences for a literary work.

\section{Discussion}

When rendering spoken language varieties into the target language, the translator can opt for different strategies. Here, the problematic notion of faithful translation is even more problematic and hardly applicable, as a translation which is loyal to the original work may demand strong distancing from the structures of the source language. The translation of linguistic variation always requires special creativity: Translating is rewriting, and the target text must be newly created with the special means of the target language. Regardless of whether the translator renders a source text marked with spoken language diversity into standard language or creates an illusion of orality through means in the target language, the translator's voice is always visible or audible. There is no neutral solution behind which the translator can hide.

Even though we identified a strong tendency towards levelling-out spoken variation in the source texts, counter examples with rich variation were also found. Thus, we cannot speak of translation universals. Considering the difficulty of rendering spoken language features into the target language, and taking account of external factors such as readers' attitudes and expectations, the tendency of normalization is unsurprising. Retaining the variation of the source text and transmitting it in the target text demands special skills, whereas the choice of standard language is a simpler solution and is less timeconsuming. Moreover, an experienced translator of a high prestige novel is in a different situation from that of an inexperienced translator of less prestigious texts (cf. Leppihalme 2000: 266). In addition, readers cannot know which kind of variation is used in the source text and the extent to which it is has been 
rendered into the target language; that is, they must take the linguistic style of the target text at face value.

We found differences in translations of spoken language features across time and genres, but what do they reveal about the extent and nature of the underlying norms? Ideally, norms offer routine solutions and help the translator make decisions. The translation of literary spoken language, however, is never a routine solution. As we have also seen, different translations are possible during the same literary period. Consequently, it is clear that the norms in question are not obligatory. Nevertheless, to a certain extent, they can be prohibitive (for example preventing the use of slang). Mostly, however, they are permissive and express preferences (cf. Hermans 1999: 83). As our study has shown, different, even conflicting, norms coexist: Translation prizes may be awarded on the grounds of a work's rich language variation, while readers and critics may disapprove of its use of colloquial language. From the perspective of the translator, norms can be competing: Using a target language dialect may be too domesticating; on the other hand, it could be a valid strategy for retaining the spirit of the source text.

Rather than being stable, norms are in a constant state of flux, and breaking existing norms may result in new norms, as the example of Saarikoski's translation of The Catcher in the Rye demonstrates. Norms are not only regulative but also constitutive. In ethnomethodology norms are regarded as tools for making sense of interaction; when orienting to norms, actors make their activities understandable and indicate how they should be understood (Heritage 1984). Although one can act against the prevailing norms, the meaning of the action may be difficult to understand and thus require account. In the case of translations of romantic literature if the language is not standard, can the text be received by readers and critics as representative of the genre?

The present study focused solely on investigating norms concerning the translation of literary spoken language and its variation. However, it should be emphasized that translating is also regulated by other norms, for example by the norm of the use of correct language. Finally, not all behaviour can be attributed to underlying norms. After all, a translation is always the creation of the translator and the outcome of his or her individual solutions. Translators are active agents who do not simply comply with norms but are also innovative (cf. Sela-Sheffy 2005). The innovative role they adopt may depend on the context of the literary field as well as on the translator's status.

\section{References}

Baker, Mona (1993). Corpus Linguistics and Translation Studies. Implications and Applications. Text and Technology: In Honour of John Sinclair, eds. Mona Baker, Gill Francis \& Elena Tognini-Bonelli. Amsterdam: Benjamins, 233-250.

Ben-Ari, Nitsa (1992). Didactic and Pedagogic Tendencies in the Norms Dictating the Translation of Children's Literature. The Case of Postwar German-Hebrew Translations, Poetics Today 13(1), 221-230. 
Ben-Shahar, Rina (1994). Translating Literary Dialogue. A Problem and its Implication for Translation into Hebrew, Target 6(2), 195-221.

Berthele, Raphael (2000). Translating African-American Vernacular English into German. The Problem of "Jim" in Mark Twain's Huckleberry Finn, Journal of Sociolinguistics 4(4), 588-613.

Blum-Kulka, Shoshana (1986). Shifts of Cohesion and Coherence in Translation. Interlingual and Intercultural Communication. Discourse and Cognition in Translation and Second Language Acquisition Studies, eds. Juliane House \& Shoshana BlumKulka. Tübingen: Narr, 17-35.

Brodovich, Olga I. (1997). Translation Theory and Non-Standard Speech in Fiction, Perspectives. Studies in Translatology 5(1), 25-31.

Carkeet, David (1979). The Dialects in Huckleberry Finn, American Literature, 51(3), 315-332.

Chesterman, Andrew (2004). Beoynd the Particular. Mauranen \& Kujamäki, 39-55.

--- (2006). A Note on Norms and Evidence. Translation and Interpreting - Training and Research, eds. Jorma Tommola \& Yves Gambier. Turku: University of Turku, 13-19.

Czennia, Bärbel (2004). Dialektale und soziolektale Elemente als Übersetzungsproblem. An International Encyclopedia of Translation Studies / Encyclopédie internationale de la recherche sur la traduction / Ein internationales Handbuch zur Übersetzungsforschung, eds. Harald Kittel, Armin Paul Frank, Norbert Greiner, Theo Hermans, Werner Koller, José Lambert \& Fritz Paul. Berlin: Walter de Gruyter, 505-512.

Englund Dimitrova, Birgitta (1997). Translation and Dialect in Fictional Prose - Vilhelm Moberg in Russian and English as a Case in Point. Norm, Variation and Change in Language. Proceedings of the Centenary Meeting of the Nyfilologiska sällskapet, Nedre Manilla 22-23 March 1996. Stockholm: Acta Universitatis Stockholmiensis, 49-65.

Eskola, Eija (2007). Hedwig Courts-Mahler. Riikonen et al. 1, 369-370.

Even-Zohar, Itamar (1990 [1979]). Polysystem Theory, Poetics Today 11(1).

Findlay, Bill (2000). Standard into Dialect. Missing the Target. Moving Target, ed. Carole-Anne Upton. Manchester: St Jerome Publishing, 35-46.

Finnish Book Publishers Association (2016): Statistics. http://www.kustantajat.fi/pages/k9/tilastot/?lang=en-gb

Häkkinen, Kaisa (1994). Agricolasta nykykieleen. Suomen kirjakielen historia. Helsinki: WSOY.

--- (2007). Kielen kehitys ja suomennoskirjallisuus. Riikonen et al. 1, 162-171.

Heritage, John (1984). Garfinkel and Ethnomethodology. Cambridge: Polity Press.

Hermans, Theo (1991). Translational Norms and Correct Translation. Translation

Studies. The State of the Art. Proceedings of the First James S Holmes Symposium on Translation Studies, eds. Kitty M. van Leuven-Zwart \& Ton Naaijkens.

Amsterdam: Rodopi, 155-178.

--- (1999). Translation in Systems. Descriptive and System-oriented Approaches Explained. Manchester: St. Jerome Publishing. 
House, Juliane (1973). Of the Limits of Translatability, Babel 4(3),166-167.

Kallio, V. J. (1939). Fennica-kirjallisuuden salanimiä ja nimimerkkejä vuoteen $1885=$ Signatures et pseudonymes de la littérature finlandaise jusqu'en 1885 . Helsinki: SKS.

Kovala, Urpo (1992). Väliin lankeaa varjo. Angloamerikkalaisen kaunokirjallisuuden välittyminen Suomeen1890-1939. Nykykulttuurin tutkimusyksikön julkaisuja 29. Jyväskylä: Jyväskylän yliopisto.

Laitinen, Lea (2011). Kielitaiteilijat ja kielitieteilijät. Juhani Aho ja puhutun kielen kuunteleminen. Pariisista lisalmeen. Kansainvälinen ja kansallinen Juhani Aho, eds. Jyrki Nummi, Riikka Rossi \& Saija Isomaa. Suomalaisen Kirjallisuuden Seuran Toimituksia 1350, Tiede. Helsinki: SKS, 153-185.

Larsson, Mats (1992). Från tjeckiska till svenska. Översättningsstrategier för litterärt talspråk. Meddelanden från Institutionen för nordiska språk vid Stockholms universitet 32. Stockholm: Stockholms universitet.

Lavoie, Judith (2002). Traduire pour aseptiser. Huck Finn revu et corrige par W.-L. Hughes, Babel 48(3), 193-216.

--- (2007). Mark Twain vs. William-Little Hughes. The Transformation of a Great American Novel. Translation - Reflections, Refractions, Transformations, eds. Paul St-Pierre \& Prafulla C. Kar. Amsterdam: Benjamins, 95-106.

Leppihalme, Ritva (2000). The two Faces of Standardization. On the Translation of Regionalisms in Literary Dialogue, The Translator 6(2), 247-269.

Lindqvist, Yvonne (1995). Spoken Language in Literary Prose - a Translation Problem. A Case study of The Catcher in the Rye by J.D. Salinger. Translation and the Manipulation of Discourse. Selected Papers of the CETRA Research Seminars in Translation Studies 1992-1993, ed. Peter Jansen. CETRA - The Leuven Research Center for Translation, Communication and Cultures, 77-107.

Malmkjær, Kirsten (2008). Norms and Nature in Translation Studies. Incorporating Corpora. The Linguist and the Translator, eds. Gunilla Anderman \& Margaret Rogers. Clevedon: Multilingual Matters, 49-59.

Mauranen, Anna \& Kujamäki, Pekka (eds.) (2004). Translation Universals. Do They Exist? Amsterdam: Benjamins.

Nevalainen, Sampo (2004). Colloquialisms in Translated Text. Double Illusion?, Across Languages and Cultures 5(1), 67-88.

Niemi, Juhani (1975). Populaarikirjallisuus Suomessa. Huokean viihdekirjallisuuden osakulttuurin erittelyä. Porvoo: WSOY.

Paloposki, Outi (2002). Variation in Translation. Literary Translation into Finnish 18091850. Department of Translation Studies, University of Helsinki.

--- (2007). Suomentaminen ja suomennokset 1800-luvulla. Riikonen et al. 1, 102-126.

Paunonen, Heikki (1976). Kotikielen Seura 1876-1976, Virittäjä 80(3), 310-432.

Pym, Anthony (1998). Method in Translation Study. Manchester: St. Jerome Publishing.

Ramos Pinto, Sara (2009). How Important is the Way You Say it? A Discussion on the Translation of Linguistic Varieties, Target 21(2), 289-307. 
Riikonen H. K., Kovala, Urpo, Kujamäki, Pekka \& Paloposki, Outi (eds.) (2007). Suomennoskirjallisuuden historia 1-2. Suomalaisen Kirjallisuuden Seuran Toimituksia1084. Helsinki: SKS.

Schäffner, Christina (1999). The Concept of Norms in Translation Studies. Translation and Norms, ed. Christina Schäffner. Clevedon: Multilingual Matters, 1-8.

Schwitalla, Johannes \& Tiittula, Liisa (2009). Mündlichkeit in literarischen Erzählungen. Sprach- und Dialoggestaltung in modernen deutschen und finnischen Romanen und deren Übersetzungen. Tübingen: Stauffenburg.

Sela-Sheffy, Rakefet (2005). How to be a (Recognized) Translator. Rethinking Habitus, Norms and the Field of Translation, Target 17(1), 1-26.

Sevänen, Erkki (2007). Suomennoskirjallisuuden määrällisestä kehityksestä. Riikonen et al. 2, 12-22.

Suominen, Oili (2005). Kahden herran palvelijana. Ajatuksia Günter Grassin suomentamisesta. Suom. huom. Kirjoituksia kääntämisestä, ed. Kristiina Rikman. Helsinki: WSOY, 97-114.

Tarkka, Pekka (1996). Saarikoski kääntäjänä, Kääntäjä 10, 1-3.

Tiittula, Liisa (2014). Lexikalische Wiederholungen im literarischen Text. Eine exemplarische Analyse eines deutschen Ausgangstextes und seiner finnischen Übersetzung. Kommunikative Routinen. Formen, Formeln, Forschungsbereiche, eds. Leena Kolehmainen, Hartmut E. H. Lenk \& Liisa Tiittula. Frankfurt/M.: Lang, 237-257.

Tiittula, Liisa \& Pirkko Nuolijärvi (2013). Puheen illuusio suomenkielisessä kaunokirjallisuudessa. Suomalaisen Kirjallisuuden Seuran Toimituksia 1401, Tiede. Helsinki: SKS.

Tirkkonen-Condit, Sonja (2004). Unique Items. Over- or Under-Represented in Translated Language? Mauranen \& Kujamäki, 177-184.

Toury, Gideon (1980). In Search of a Theory of Translation. The Porter Institute for Poetics and Semiotics, Tel Aviv University.

--- (1995). Descriptive Translation Studies and Beyond. Philadelphia: Benjamins. 